\title{
Developing Business Translation Material for English Education Department Students at University of Muhammadiyah Gresik
}

\author{
Fajriyani Erisafitri \\ Universitas Muhammadiyah Gresik \\ Jl. Sumatra No.101 GKB \\ E-mail: fajriyani.safitri@gmail.com
}

Received: July 10, 2017

Accepted: August 17, 2017

Published: August 31, 2017

doi:10.7575/aiac.ijels.v.1n.1p.1

URL: http://dx.dei.org/10.7575/aiac.ijels.v.1n.1p.1

\begin{abstract}
Translation is a language competence which combines reading and writing skills. It is worth the learning, especially for English department students. Through learning translation, the students are able to not only enhance their translation skill, but also prepare for the challenges of finding jobs after they graduate. One of the useful translation topics to be learned is business. Based on those reasons, this study was intended to create a business translation material for English education department students at University of Muhammadiyah Gresik. This study employed Research and Development design and Asmara's ADDIE (Analyze, Design, Develop, Implement, Evaluate) model. 21 senior students of English language education department at University of Muhammadiyah Gresik who have passed translation course were involved in the study. The need analysis data were gathered through questionnaire. The result of the questionnaire was considered in creating the material, which is developed following Harmer's ESA (Engage, Study, Activate) approach. The need analysis results reveal that the students need the material which focuses on enhancing translation skills and enriching vocabulary as well as provides basic information about business letters as the topic of the material. From the result of expert validation and questionnaire after try-out, some adjustments are made to the material. The adjustments are presenting more explanation of business letters material, adding more vocabularies, giving some pictures, and providing conclusion at the end of each chapter. To conclude, the students need the material which focuses on not only skills enhancement, but also vocabulary enrichment. This study involved students who have passed translation course, expected to use their experience in translation learning to be considered in creating the material. Based on the results, the recommendations are given to English language education department students, translation lecturers, and future researchers to use both the data of the results and the product of this study effectively.
\end{abstract}

Key words: Reading Business Translation, Translation Material.

\section{Introduction}

Being English language teachers is the main goal for most students after graduating from English language education department. However, along with the continuously growing number of English language education department graduates, the future challenges of the graduates become more demanding. The graduates who have teaching skills only will have smaller opportunity to look for jobs other than teaching. If they could not get the teaching job, they will be unemployed and what they have learned will become worthless.

One thing that can be accomplished by the graduates to resolve the mentioned problem and being more prepared for future challenge is to master other skills, such as translation, interpreting, computer operating, entrepreneur, and other supporting skills. One common way performed by the English language education department graduates is creating English courses, whether the course is held at home or the certified English course with actual classrooms. Nevertheless, together with the constant increasing English courses, the aforementioned solution will be less prospective as future career. Another prospective skill for future career is translation skill. It is because translation is an essential enterprise in the twenty-first century (Mir, 2015). It can also be seen from the high demand of translation in many fields. In brief, a plausible skill which is potential for future career is translation.

On the other hand, more translation training programmes are available, like translation course in translation major or the courses included in language or language education major. University of Muhammadiyah Gresik itself provides translation course for English language education department students. The translation course is held once a week with approximate time two hours in a meeting for one semester, with fourteen meetings at the most. The learning resource, which commonly used, is a translation book which presents the theory only. The materials taught in the 
translation class are mostly focus on the strategies of translation. As for the type of texts being translated are mainly about science, such as academic, literature, technical texts.

From the previous description of the course, the researcher noted some important points concerning on the available course material. The learning resources provided for students need to be enhanced and diverse. Essentially, sufficient learning resource is required to provide students with helpful assistance in their learning inside as well as outside the classroom. The existed material, which provides translation theories, should be completed with enough translation exercises as media for students to practice what they have learned. On the other hand, the type of texts being presented should be varied to help the students expand their knowledge about the variety of texts as well as develop their skills in translating many types of texts. Hence, students need more support to help them learn better in translation class, especially the support in the form of translation material.

With regard to translation material, Stewart (2008) asserted that learning resources for translation into foreign language are limited. In addition, most books on translation found are for professional use. Furthermore, there are several researchers who have conducted the study about the students' need analysis in learning translation, such as Mutlu (2004), Karoly (2011), and Wang (2014), but, the study on developing translation material has not been found yet. One of the translation worth to be learned is business. By learning business translation, students' knowledge about the characteristics of special text will become wider; students' experience in translating special terms will be increased together with their translation skill enhancement; students' writing skill will also be improved along the way. In the correlation with translation as profession demands, translation in business is also one of the most demanding translation jobs, especially in industrial area, like Gresik. Because of this research is done in Gresik and most of the students in University of Muhammadiyah Gresik are from or live in Gresik, the researcher puts business topic into this research.

As the reasons mentioned above, this research proposes one way to assist the students to learn translation by providing translation materials focusing on business field. Through the materials, the learners will have more opportunity in learning translation to improve their translation competences, to broaden their knowledge, as well as in getting the job more easily; teachers to have more guidance in teaching translation; and future researchers to have a resource in studying the materials in learning translation, especially in business translation.

\section{Methods}

This study applies Research and Development as the design for the reason that it is intended to develop translation material for English language education department students. Bock (2001) in Putra (2013) defined that research is a process of acquiring new knowledge and development is a process of applying knowledge to create a new device. The product of this study will be in the form of teaching/learning material.

In developing materials, some steps should be followed systematically by the researcher. A variety of instructional development models have been proposed by experts. One of the most used models is ADDIE model, which is originally formulated by Steven J. McGriff. The elements which build ADDIE are Analyze, Design, Develop, and Evaluate (Welty, 2007).

Figure 3.1: McGriff's ADDIE Model

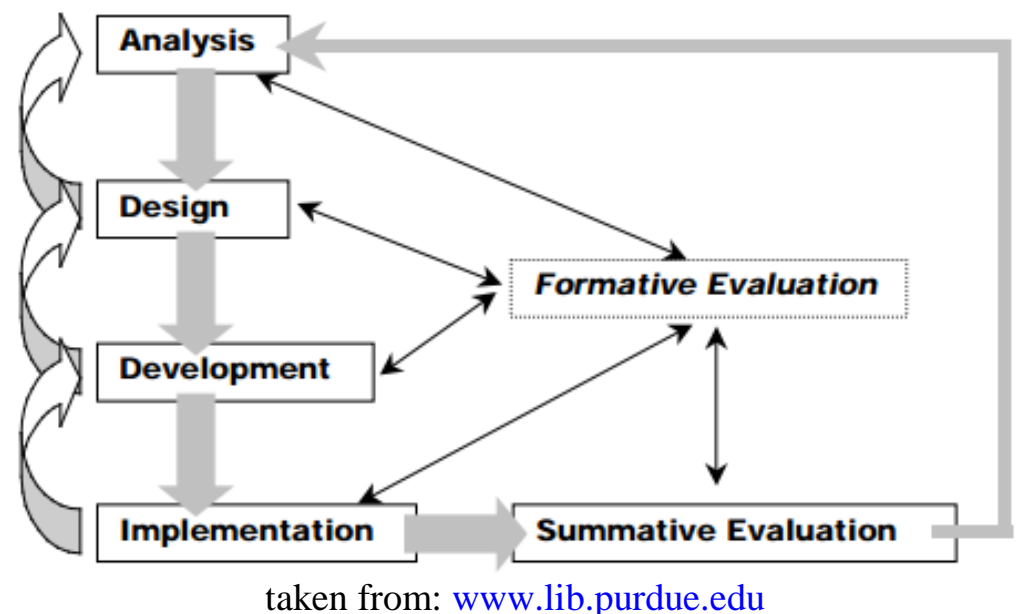

In this study, the researcher uses the ADDIE model which is adapted by Asmara (2012), cited from Februanti (2015). The diagram of the ADDIE model is as the following:

Figure 3.2: Asmara's ADDIE Model 


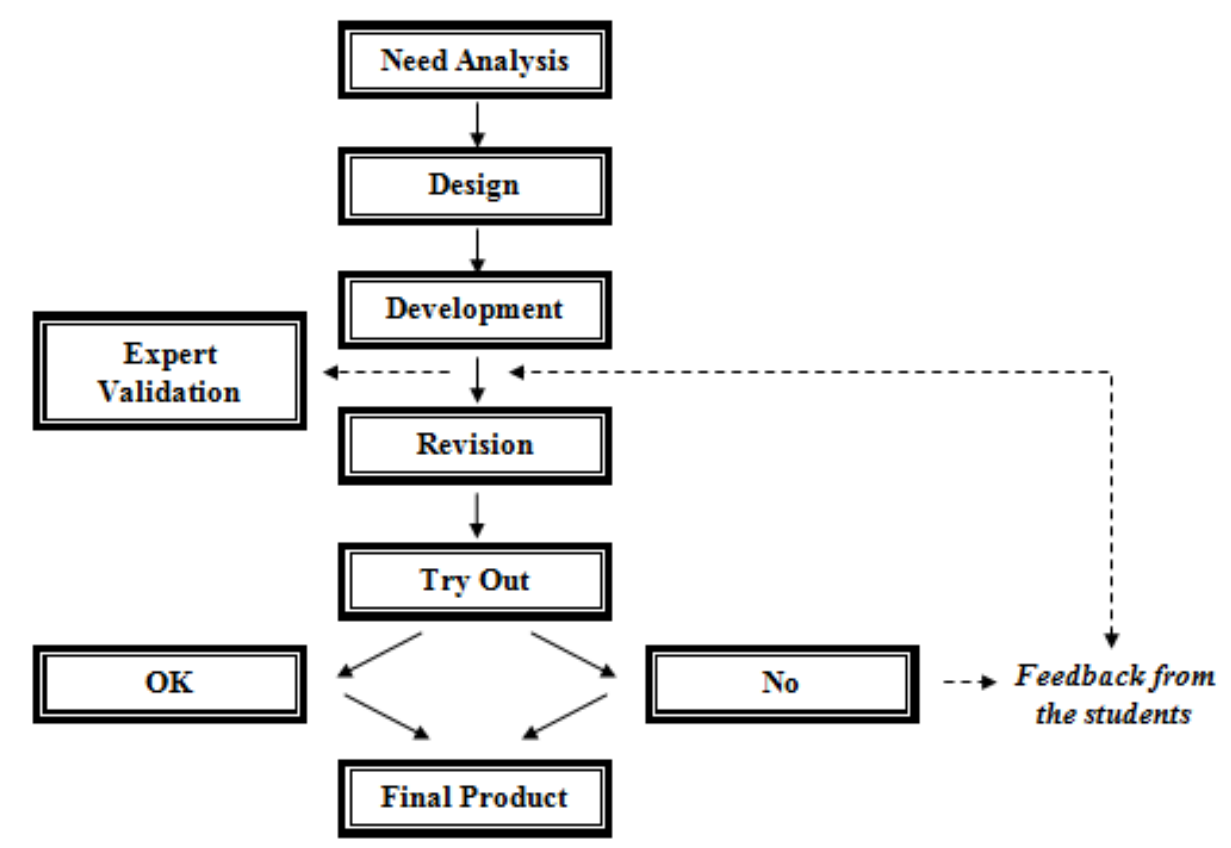

Figure 3.2: Asmara's ADDIE Model

Subject

The subjects of this study are twenty-one students of English language education department at University of Muhammadiyah Gresik. In line with one of the intentions of this study, process-oriented interpretation, all of the students chosen to participate in this study have passed the translation course. It is because they have experienced translation learning so that they can share their process-oriented interpretation in teaching learning translation while relating to their experience. In obtaining the understanding the needs of learning translation, twenty-one students are invited to participate in this study.

The Instruments of Data Collection

During the data collecting, the researcher uses two kinds of instruments, they are need analysis questionnaire for students; and evaluation checklists for both experts and students. The first instrument is need analysis questionnaire. The questionnaire which is used in this study is adapted from Wang's (2014) student-centred translation course need analysis for EFL college students. The questionnaire consists of fifteen items with the distribution of six multiple choice questions and nine essay questions. For the information being sought in the questionnaire, one item is about the goal of the participant in learning translation, five items are about their experience in learning translation, two items are about the material in learning translation in general, and seven questions are about the material in learning translation concerning business topic. The data of the questionnaire will be gathered from the students of English language education department who have passed the translation course in University of Muhammadiyah Gresik to seek the needs of the students in learning translation.

The second instrument is evaluation checklist. There are two types of evaluation checklist, for the experts and for the students. For the experts, the data of the checklist will be gathered from the lecturers as the experts of translation material and the material concerning the business topic. This type of checklist will be used to understand opinions of the experts about the material and to test the validity of the developed translation material. On the other hand, the checklist for the students will be collected from the students who take part in the try-out of the material to understand the comprehension of the students on the presented materials and to get comments as well as feedbacks on learning translation using the given material.

\section{The Procedure of Developing Business Translation Material}

Need Analysis

The first step in developing material is need analysis. In this step, the researcher will gather the data from the subjects through need analysis questionnaires (Appendix 1) to understand their needs in learning translation. The questionnaire consists of four parts, each part with different focus: the learning goal, the preferences on the content of the material, the preferences on learning activities, and the preferences on learning evaluation. To avoid the ambiguity and other problems of the questionnaire during the data gathering, a pilot study to test the questionnaire will be done by inviting two students. From the gathered data, the researcher will be able to determine the appropriate material to be presented in the product of this study. 


\section{Design Instructional}

The researcher will do the planning of the material according to the collected data. First, the researcher will formulate the syllabus for the material. The syllabus will be designed to match the needs of the subjects. Second, the researcher will make the draft of the material. The draft will cover the content of the material, including chapters with activities, exercises, and related information.

In creating the material, the researcher will follow Harmer's ESA (Engage, Study, Activate) approach. In the engage stage, an activity is provided to motivate the students before they start to study the material. In the study stage, the material is presented to be learned by the students. In the activate stage, the exercises are provided to check the understanding of the students on the material presented in the previous stage. In this study, the engage stage will provide the exercise of vocabularies relating to the material that will be learned. In the study stage, the material will be presented. For the activate stage, the exercises of sales letter and translation will be provided.

\section{Developing Material}

In the developing step, the researcher will follow the draft of the material, focusing on content, which has been prepared in previous step. Next, the researcher will complete the material with opening and closing attributes, such as preface, table of content, references, etc. By providing those mentioned elements, it is hoped that the material will be helpful for students to learn translation inside and outside the classroom.

The first chapter will present the material about vocabularies, characteristics, and translation steps of sales letter along with the exercises. In the second chapter, the material about vocabularies, characteristics, and translation steps of inquiry letter will be presented with exercises. The third chapter will present the material about vocabularies, characteristics, and translation steps of order letter along with the exercises. In the fourth chapter, the material about vocabularies, characteristics, and translation steps of complaint letter will be presented with the exercises. The fifth chapter will present the material about vocabularies, characteristics, and translation steps of adjustment letter along with the exercises. Furthermore, exercises will be provided.

\section{Expert Validation}

After creating the material, the researcher will invite the experts, who are the lecturers of translation course at University of Muhammadiyah Gresik and who master about business texts since the material of this study is dealing with, to evaluate the whole material, including content and design, and to verify the validity of the material according to the knowledge owned by the experts of good translation material. The data will be recorded in the form of evaluation checklist for experts (Appendix 2). After the evaluation process, the researcher will decide which parts of the material to be revised.

\section{Try-out of Material}

After developing the material, the researcher will conduct the try-out to five participants. The researcher will arrange the time of the try-out according to the availability of the students. First, the participants was given time to read the material. Then, they were asked to do some exercises provided in the material. After that, the participants were requested to fill out the questionnaire to know their comments and suggestions toward the material. The questionnaire is purposed on knowing their feedback about the content and design of the material. Their feedbacks will be used as the basis by the researcher to modify the material.

\section{Revision of Material}

After the try-out, the researcher will modify the revised material. The modification is according to the feedbacks given by the students who have done the try-out. So, it is expected that the final product of this study will fulfil the students need well.

Final Product

The last step is final product. After being revised, the material is ready to be used by the teachers and students in teaching learning translation.

The first to fifth chapter will provide the material about five different types of business letter. Each chapter will focus on the characteristics, vocabularies, and translation of the business letter type being presented with the exercises.

\section{Findings}

The result of need analysis explored the needs of English education department students in learning translation from English into Bahasa Indonesia. Fifteen questions were asked to the participants to gather their needs. The results are described below in two parts: target needs and learning needs. The need analysis questionnaire can be seen in appendix 1 .

\section{Target Need}

Nine questions were asked to the participants to gather the information about the participants' target needs. The results are described in this section. 
The first question was about the participants' goal in learning translation. The table shows that the goal viewed as the most important in learning translation was improving the ability to translate $(81 \%)$, while understand the weakness in learning English viewed as the least important goal $(0 \%)$. The next important goal was enriching the vocabulary $(67 \%)$. Other less important goals were improve the ability to understand the text (19\%), increase the motivation to learn English (14\%), practice using monolingual dictionary effectively (14\%), understand differences between English and Indonesian grammar (10\%), and practice using bilingual dictionary effectively (5\%).

The responses to the first question indicate that the participants are aware of the vocabulary mastery importance in learning translation other than the translation skill itself. It is supported by Febrianingrum (2008) who stated that there is a positive correlation between vocabulary mastery and the ability to translate English text into Indonesian. So, the material of this study should focus on improving the students' translation skill as well as assist ing the students to learn the language.

The second question was about the difficulties the participants encountered when they learned translation. The table indicates that translate specific terms was the most difficult part in learning translation $(86 \%)$, whereas master English vocabulary was the least difficult part $(10 \%)$. Other difficult parts of learning translation were finding the equivalent words in the dictionary $(67 \%)$ and maintain the style of the source text $(43 \%)$.

Relating to the response of the second question, Olteanu (2012) agreed that one basic difficulty in translating a text is the difficulty in deciding the exact equivalent of the word from the source text. The responses imply that vocabulary mastery should be paid special attention in designing the material for translation learning. Not only because it is important in translation process, but also because both problem areas, translating specific terms and finding the equivalent words, are included in vocabulary mastery. As Marmaridou (1996) in Stewart (2008) mentioned that the problematic area should be focused on when assisting the students in learning translation. Additionally, making students aware of their limitation and helping them prepare to solve the problem are necessary in translation teaching learning (Beeby, 1998 in Stewart, 2008). Thus, the product of this study should provide the material which focuses on vocabulary mastery.

The third question was whether the participants needed to know the definition of business translation. Twenty participants $(95 \%)$ responded that they needed to know the definition of business translation. One participant $(5 \%)$ answered that the definition of business translation was not necessary.

The fourth question was about whether the participants need to know the definition of business document. All of the participants $(100 \%)$ answered that they needed to know the definition business document. The fifth question was whether the participants need the information about types of business document. Twenty participants (95\%) responded that they needed to know the types of business document. One participant (5\%) answered that the information about the types of business document was not necessary.

The sixth question was whether the participants need the information about function of each business document All participants (100\%) answered that they needed the information about the function of each type business document.

The seventh question was whether the participants need the information about formats of business document. Twenty participants (95\%) responded that they needed the information about formats of business document. One participant (5\%) answered that the information about formats of business document was not necessary.

The eighth question was whether the participants need the information about parts of business document. Twenty participants $(95 \%)$ answered that they needed the information about parts of business document such as introduction, body copy, and conclusion. One participant (5\%) responded that the information about parts of business document was not necessary.

The ninth question was whether the participants need the information about function of each part of business document. Nineteen participants $(90 \%)$ responded that they needed the information of function of each part of business document: to introduce the intention of writing the document, to inform the recipient or express what the sender expects from the recipient, and to thank the sender as well as conclude the document. Two participants (10\%) answered that the information about function of each part of business document was not necessary.

The results of the third to ninth questions show that, as business translation is a new and specific topic to the students, the information relating to business topic is needed by the students to help them get the most of their translation learning. Some participants elaborated that the information about business translation definition will help them understand better about the context of the text that they are about deal with. In other words, the information about business topic, including business translation definition; business document definition; and each type of business document along with the definition, format, function, parts, and function of parts are necessary and should be included in the product of this study.

\section{Learning Need}

Six questions were asked to obtain the participants' learning need. The results are described in this part.

The first question was about the opinion of the participants about the difficulty level of translation. Most participants $(76 \%)$ perceived that translation was somewhat difficult. Four participants (19\%) answered that translation was difficult. One participant $(5 \%)$ responded that translation was very difficult. 
The second question was about the factors of their difficulties in learning translation. Six participants (29\%) mentioned that lack of understanding the vocabulary, especially special terms was one factor of translation difficulty. Three participants (14\%) said that lack of practice was another factor of translation difficulty. The rest of the participants preferred not to answer.

The responses to the second questions that they still need assistance in learning translation, especially in learning vocabulary about specific terms and practicing in translating texts. It means that the material should include vocabulary about specific terms. Concerning the difficulty in understanding specific term, Olteanu (2012) stated that when dealing with a specialized text, the problem of understanding the concepts and vocabulary may occur. On the other hand, relating to the responses to the second question that lack of practice is one reason of translation difficulty, Benfoughal (2010) stated that a lot of practice is necessary for translator, through more practices they will become more familiar with the target language, get some hints of translation, and gain experience. Benfoughal (ibid) also added that the experience gained from practices is expected to make them translate more easily, accurately, and effectively. Furthermore, Wong and Shen (1999) said that experience plays an important role in translation, especially to overcome the problems during the translation process.

The third question was about how the participants solve the difficulties in learning translation. Five participants (24\%) mentioned doing a lot of translation practice as the solution. Five participants $(24 \%)$ said that browse the internet to get the information about special terms as another solution. Five participants $(24 \%)$ answered that learning more vocabulary as the solution. The rest of the participants chose not to answer.

The result of the third question suggests that the students can be assisted in learning translation by providing more translation exercises and vocabulary exercises to help them practice more as well as to improve their vocabulary enrichment and understanding. Also, they can be assisted in using the sources from the Internet effectively during their translation learning. So, the researcher should create the material with exercises on both translation and vocabulary.

The fourth question was about the translation materials the participants have learned. Translation strategies was the material most participants $(67 \%)$ answered as the material that they have learned. Conversely, the use of punctuation in English and Bahasa Indonesia was the material least chosen $(14 \%)$ by the participants. Other materials they have learned were the differences between English and Indonesian grammar (57\%), vocabulary of specific terms (52\%), translation theories $(33 \%)$, and common errors in translation (33\%)

The fifth question was about the opinion of the participants about the materials needed in learning translation. Vocabulary of specific terms was the material most participants answered as necessary (81\%). Translation theories were the material least chosen $(14 \%)$ by the participants as necessary. Another material they perceived as necessary was translation strategies $(67 \%)$. Other materials they viewed as less necessary were common errors in translation (48\%), the differences between English and Indonesian grammar (38\%), and the use of punctuation in English and Bahasa Indonesia (19\%).

The result of the fifth question, relating to the fourth question, indicates that the participants considered the material about vocabulary of specific terms and translation strategies as necessary while the differences between English and Indonesian grammar was not really necessary. So, the material of this study should provide material about vocabulary of specific terms and translation strategies. Wang (2014) agreed the availability of language knowledge in the translation material should be considered when providing the material for the students.

The sixth question was about the preferences of the participants on activities in learning translation. Peer editing was the activity preferred by most participants $(62 \%)$. Practice to understand text was the activity least preferred by the participant (19\%). Another activity they preferred was translate text in group (52\%). Other activities they less preferred were analyse the translation and present the result (48\%) and translate text individually (43\%).

The response to the sixth question reveals that the participants considered the activities which involve teamwork between the participants as the activities they preferred. It is helpful not only to point out the mistakes they make in their translation, but also to share the strategies they use to solve the problems during the translation. This suggests that the researcher should provide the material with the activities which involve teamwork. This is agreed by Barros (2011) who mentioned that the importance of teamwork has been continuously increasing in today professional translation world. Barros (ibid) also suggested that teamwork be implemented in translation teaching learning because of its role in carrying out the students' motivat ion in achieving the goals through a mutual effort and the responsibility assumed by each team member. Wang (2014) also mentioned that the students will be more likely to be engaged when they practice translation in group.

\section{Conclusion}

According to the result of this study, the students need the material which focuses on both theory and practice. Business translation material needed by the students is the material which focuses on translation skill improvement, vocabulary enrichment, and basic knowledge about business letter. The result of this study reveals that the students need the material about vocabulary of special terms used in each type of business letter, and strategies to translate each type of the letter, and basic information about business letter such as definition, common format, types, function, parts, and function of parts of business letters. 
It can be concluded that the students need assistance in learning business letter, vocabularies, and translation strategies. It means that the material should provide the information about business letter, vocabulary of business letter, translation strategies, and exercises to help them practice their translation skill. However, the product of this study is created to meet the needs of the students who have similar difficulty level in learning translation as the participants of this study and cannot be generalized for all students which have different difficulty level in learning translation.

\section{References}

Aguado-Giménez, P., \& Pérez-Paredes, P. (2005). Translation Strategies Use: A Classroom-Based Examinat ion of Baker's Taxonomy. Meta: journal des traducteurs/Meta: Translators' Journal, 50 (1), 294-311. DOI: 10.7202/010675ar

Azmi, I. F. (2012). Students' Difficulties in English-Indonesian Translation of Specialized Terminologies. Semarang: Universitas Negeri Semarang. Retrieved from http://lib.unnes.ac.id

Barros, E. H. (2011). Collaborative Learning in the Translation Classroom: Preliminary Survey Results. The Journal of Specialised Translation, 6, 42-60. Retrieved from http://www.jostrans.org

Benfoughal, A. (2010). Students' Difficulties and Strategies in Translation: The Case of Third Year Students, Mentoury University Constantine. Mentoury: University of Constantine. Retrieved from: http://bu.umc.edu.dz

Biel, L. (2011). Professional Realism in the Legal Translation Classroom: Translation Competence and Translator Competence. Meta: journal des traducteurs/Meta:

Translators' Journal, 56 (1), 162-178. DOI: 10.7202/1003515ar

Bowie, J. L. (2007). Four Types of Business Letter. Retrieved from http://www.rhetcomp.gsu.edu

Chien, C. (2015). EFL Undergraduates' Awareness of Translat ion Errors in Their Everyday Environment. Journal of Language Teaching and Research, 6 (1), 9198. DOI: http://dx.doi.org/10.17507/jltr.0601.11

Febrianingrum, I. W. (2008). Correlation Between Vocabulary Mastery Andability in Translating English Text into Indonesian. Retrieved from https://core.ac.uk

Februanti, E. N. (2015). Developing Conversation Partner Module for University of Muhammadiyah Gresik. Unpublished Thesis. Gresik: Universitas Muhammadiyah Gresik.

Harmer, J. (1998). How to Teach English. Essex: Pearson Education Limited.

Hutchinson, T., and Waters, A. (1987). English for specific purposes: A learningcentered approach. Cambridge: Cambridge University Press.

Karjo, C. H. (2015). Problems in Translating Legal English Text into Indonesian. Arab World English Journal, 6 (2), 352-364. Retrieved from www.awej.org

Károly, A. (2011) Exploring Learners' Needs and Expectations: Translating EU Texts in an English Bachelor's Programme at a Hungarian College. WoPaLP, 6, 1-28. Retrieved from http://langped.elte.hu

Kolahi, S., Hajar, K. \& Elaheh, S. (2013). A Comparison of the Application of Readability Formulas in English Translation Textbooks and Their Translations. International Journal of English Language Education, 1 (1), 140-161. DOI: 10.5296/ijele.vlil.2963 
Krisetyawati, B. F. (2010). An Error Analysis on the Translation of English Noun Phrases into Indonesian of the Fifth Semester Students of the English Department of Teacher Training and Education Faculty, Sebelas Maret University in the Academic Year 2009/2010. Surakarta: Sebelas Maret University. Retrieved from https://core.ac.uk/download/

Mir, F. F. (2015). Journey of Translation From Source Language Text to Target Language Text: A Critical Study. International Journal of English Language, Literature, and Translation Studies, 2 (3), 152-157. Retrieved from http://www.ijelr.in

Mutlu, Ö. (2004). A needs analysis study for the English-Turkish translation course offered to management students of the faculty of economic and administrative sciences at Baskent University. Master Thesis. Middle East Technical University. Retrieved from https://etd.lib.metu.edu.tr/

Newmark, P. (1988). A Textbook of Translation. Hertfordshire: Prentice Hall International.

Olteanu, A. (2012). Errors and Difficulties in Translating Economic Texts. Retrieved from http://lectura.bibliotecadigitala.ro

Olvera-Lobo, M. D., et al. (2005). Translator Training and Modern Market Demands. Perspectives: Studies in Translatology, 13 (2), 132-142. Retrieved from http://eprints.rclis.org

Priyono. (2005). Lexical Constraints in Translation and Learning English as a Foreign Language in Indonesia. TEFLIN, 16 (2). Retrieved from http://www.journal.teflin.org/

Putra, N. (2013). Research \& Development. Jakarta: Rajawali Pers. Qassim, A. Sh. (n.d.). Translation Grammatically Viewed. Retrieved from http://www.uobaghdad.edu.iq

Songhori, M. H. (2008). Introduction to Needs Analysis. English for Specific Purposes World, (4), 1-25. Retrieved from www.esp-world.info

Stewart, D. (2008). Vocational Translation Training into a Foreign Language. TRAlinea, 10. Retrieved from ht t p: // www. int $\mathrm{r}$ alinea. org/ar chive/ ar t icle/ 1646

Wang, H. (2014). An Analysis of EFL Learners' Needs for Student -Centered Translation Course Design. Study in English Language Teaching, 2 (1), 76-94. Retrieved from www.scholink.org/ojs/index.php/selt

Wang, L. (2016). Tips for College Science Majors in English-Chinese Translation Practice. Journal of Language Teaching and Research, 7 (2), 403-407. DOI: http://dx.doi.org/10.17507/jltr.0702.22

Welty, G. (2007). The ADDIE Model: An Instructional Generic Model. Retrieved from http://www.ivtnetwork.com

Wong, D., and Shen, D. (1999). Factors Influencing the Process of Translating. Meta: journal des traducteurs /Meta: Translators' Journal, 44 (1), 78-100. DOI: 10.7202/004616ar. Retrieved from http://www.erudit.org/004616ar

Xu, J. (2005). Training Translation in China. Meta: journal des traducteurs / Meta: Translations' Journal, 50 (1), 231-249. DOI: 10.7202/010671ar 